JARES, Vol. 5 No. 1 March, 2020; p-ISSN: 2502-826X; e-ISSN: 2503-1163

Copyrights@ Balitar Islamic University, Blitar, Indonesia;

https://ejournal.unisbablitar.ac.id/index.php/jares

\begin{abstract}
Citation: Ana Fardila, U., Mahmudatul Imamah, F., \& Sari Dewi, I. (2020). WHY ISLAM IS THE WORLD FASTEST GROWING RELIGIOUS GROUP DESPITE OF TERRORISM ISSUES? AN INITIAL RESEARCH OF TERRORISM ISSUES AND ISLAM AWARENESS. JARES (Journal of Academic Research and Sciences), 5(1), 1-13. https://doi.org/10.35457/jares.v5i1.899
\end{abstract}

\title{
WHY ISLAM IS THE WORLD FASTEST GROWING RELIGIOUS GROUP DESPITE OF TERRORISM ISSUES? AN INITIAL RESEARCH OF TERRORISM ISSUES AND ISLAM AWARENESS
}

\author{
Ucik Ana Fardila ${ }^{1}$, Fardan Mahmudatul Imamah ${ }^{2}$, Intan Sari Dewi ${ }^{3}$ \\ Institut Agama Islam Negeri Tulungagung, Jl. Sujadi Timur \\ ${ }^{1}$ Email: fardillaucikana@gmail.com, ${ }^{2}$ Email: fardanblog2015@gmail.com \\ ${ }^{3}$ Email: dewiintan123418@gmail.com
}

\begin{abstract}
Pew Research Center reported that Islam is the fastest-growing religious group in the world compared to another religious group. The research mentioned that in 2050 Islam population will be $30 \%$ of world's population while Christian will be silghtly more, $31 \%$ of world's population therefore PEW Research Center predicted that in 2100 Islam population will lead religious group's population even Christian. Terrorism news, extrimist and radical moslem group and Islamophobic culture almost in every western media platforms that rationally contradictory of reality that Islam is the fastest growing religious group. This research is to analyse terrorism issues in mass media and world's Islam population. Research conducted in qualitative descriptive by literature research methode. The results of the research showed that despite of negative stereotypes in media who tend to correlated Islam and radical moslem group through several platforms such as movie and news, the decision to join Islam was uninfluenced. The stereotypes in news and movies about terrorism, radical moslem group, and extrimist in media could become an initial point for someone to dig information about Islam although it could not concluded as a pure motivation to join Islam.
\end{abstract}

\section{Keywords: Islam Population, Terrorism, Terrorism Issues, Islam Awareness, Media, Mass Media}

\section{INTRODUCTION}

Islam awareness does not have to related to conversion althiugh in some cases when people curious about Islam, investigate and then aware about the religion, they could decided to join Islam. History noted that once conversion assumed supremacy forced pushing an individual towards conversion, as was described in Zygmunt's model (Zygmunt, 1972; Long \& Hadden, 1983). While Richard Bulliet's postulation claimed that conversion to Islam in the early Islamic period was more a matter of social behaviour than of belief (Bulliet, 1979; Salaymeh, 2016). Many studies has been done in Europe where Islam conversion growing fast in the last decades although some researchers believed that Islamic culture is not suit with European traditions such as respect for freedom of expression, women's rights, and the sharia law for state; while Europe separate church and state (Congressional Research Service, 2011). Telegraph reported that for the first time since Queen Elizabeth Islam population reached 3 millions people, fastest growing population in the last decade since 1991. At that time Islam population in Great Britain only 950.000 people (Hanggoro, 2016) ${ }^{1}$. In a study by CRS (Congressional Research Service) showed that Belgium and France have the largest proportion of Muslims as a percentage of their populations, followed by Denmark, the United

\footnotetext{
${ }^{1}$ This news shared by $11.8 \mathrm{k}$ times showed the enthusiasm of Merdeka readers about this article.
} 
JARES, Vol. 5 No. 1 March, 2020; p-ISSN: 2502-826X; e-ISSN: 2503-1163

Copyrights@Balitar Islamic University, Blitar, Indonesia;

https://ejournal.unisbablitar.ac.id/index.php/jares

\begin{abstract}
Citation: Ana Fardila, U., Mahmudatul Imamah, F., \& Sari Dewi, I. (2020). WHY ISLAM IS THE WORLD FASTEST GROWING RELIGIOUS GROUP DESPITE OF TERRORISM ISSUES? AN INITIAL RESEARCH OF TERRORISM ISSUES AND ISLAM AWARENESS. JARES (Journal of Academic Research and Sciences), 5(1), 1-13. https://doi.org/10.35457/jares.v5i1.899
\end{abstract}

Kingdom, Sweden, Germany, the Netherlands, Austria, and Switzerland; significant Muslim populations also exist in Spain, Italy, and Norway (Congressional Research Service, 2011). According to the Pew Research projections, by 2050 there will be near parity between Muslims (2.8 billion, or $30 \%$ of the population) and Christians (2.9 billion, or 31\%), possibly for the first time in history. Pew Research noted that the conversion caused mostly by migration number. It showed that Islam population by migration in North America is 2.4, without migration 1.4; in Europe Islam population by migration is 10.2 , while without migration 8.4 . The difference number between with and without migration is slight thus it could not conluded that migration is the most reason to convert Islam. Pew also showed the second best reason to join Islam is the birth rate. It said the birth rate of Islam family is 2.9 the largest number between another religion group family. But in contrast, Pew Research noted that in Europe, North America, China and Japan has low fertility and aging populations (Pew Research Center, 2015).

With many studies show the fast growing population of Islam, some observers who support unmatchness between Islam and europe culture warn of what they called as "Europe's decline" and "a possible of Islamification of Europe" (Bawer, 2006; Caldwell, 2009) while some even worry that Europe's fast growing population of Islam will transform European politics and society soon (Congressional Research Service, 2011). For this worry, some analysts assert that for the majority of Muslims in Europe, Islam is not an exclusive identity and that most European Muslims do not view being Muslim as incompatible with their national identities or their commitment to European cultural or political norms. These analyst also, however, acknowledge that there is cultural tense, but the tense attribute are more in economic and social disparities rather than religion (Rieff, 2010; Vaisse, 2010). Several scholars like Roy (2004) noted that European Muslim converts often appeal to an Islam in their own cultural and ethnic background (Özyürek, 2015; Rogozen-Soltar, 2012). From ages ago historians have come to an understanding that Islam conversion phenomenon cannot be treated from a singular perspective (Becker, 1924;1932). For example the englishman William Henry Quilliam, a Liverpool solicitor, embraced Islam in 1887 after a trip to Morocco and falled love with Islam culture (Geaves, 2010). Eaton (1996) said that Islam conversion has a very gradual process involving two discernible aspects, accretion and reform. The most famous German convert who embraced Islam in 2001, Pierre Vogel, also known as Abu Hamza, and also Sven Lau (Abu Adam) and Deso Dogg (Abu Talha Al-Almani) are German Muslim converts who propagate Islam in a minimalist puristic fashion, operating alongside Pierre Vogel in their dawah.

Several media articles tries to seek an answer to the question - why would anyone want to convert to Islam?• (Mistiaen V. (2013; Taylor \& Morrison, 2011). The CBN articles in 2015 listed 
JARES, Vol. 5 No. 1 March, 2020; p-ISSN: 2502-826X; e-ISSN: 2503-1163

Copyrights@ Balitar Islamic University, Blitar, Indonesia;

https://ejournal.unisbablitar.ac.id/index.php/jares

\begin{abstract}
Citation: Ana Fardila, U., Mahmudatul Imamah, F., \& Sari Dewi, I. (2020). WHY ISLAM IS THE WORLD FASTEST GROWING RELIGIOUS GROUP DESPITE OF TERRORISM ISSUES? AN INITIAL RESEARCH OF TERRORISM ISSUES AND ISLAM AWARENESS. JARES (Journal of Academic Research and Sciences), 5(1), 1-13. https://doi.org/10.35457/jares.v5i1.899
\end{abstract}

five main reasons to join Islam:

Islam's doctrine is simple and rational, all believers are equal, it is a "practical" religion, and lacks a priesthood. Muslim apologetics is having some effect, but these are not necessarily what is motivating Americans to become Muslim. First on his list is racism in the church. s direction and discipline." Islam offers a conversion experience and the opportunity to get one's life in order, without needing to confess ones sin and need of salvation $(C B N, 2015)^{2}$.

When radicalitation, extrimism and terrorism correlated to religion, which is mostly Islam, studies added into another studies that showed the threath of Islam conversions. Moosavi (2013) said that converts who tend to radicalisation must have difficulty in the conversion process and the struggle to have their new identity accepted by both non-Muslims and Muslims. According to terrorism experts and studies, religion in general and Islam in particular is not the main motivator of terrorism; in reality, political conflicts, warfare, and social and economic instability are the main cause (Holland, 2015). Esposito and Mogahed, the authors of the study, vehemently claimed that only $7 \%$ of the world's Muslims advocate terror. $6.5 \%$ of global Muslims justified the attacks, and another $23.1 \%$ thought that they were at least somewhat "justified." (Tausch, 2017). While Danios (2011) mentioned that in other case, muslims out of many other religious groups are most likely to be against attacks on civilians and least likely to support violence against innocent people.

\title{
METHOD
}

This reasearch conducted in qualitative descriptive by literature research methode. The literature research method of this research is to read through, sort literatures, to identify the essential attribute materials and to analyze all literatures collected. All information from a variety literatures (news, book, journal and article) indirectly deal with the object of the research. The purpose of the research is to analyse news of terrorism in media and world's Islam population thus the literatures we chose were focused in news about extrimism, radical, terrorism correlated with Islam; report about world's Islam population between another religion; research about motivation to join Islam; with some theories about conversion and several scientific sources relevant to the research.

\section{RESULTS}

In this research the studies first collected studies about Islam conversion motivation and some studies about Islam radicals, extrimism and terrorism issues. In his journal, Straus (1979) claimed that religious group manipulated new members by "brainwashing" them. A thesis by Bartoszewicz

\footnotetext{
${ }^{2}$ The article shared by $5.6 \mathrm{k}$ users and has 154 comments.
} 
JARES, Vol. 5 No. 1 March, 2020; p-ISSN: 2502-826X; e-ISSN: 2503-1163

Copyrights@Balitar Islamic University, Blitar, Indonesia;

https://ejournal.unisbablitar.ac.id/index.php/jares

\begin{abstract}
Citation: Ana Fardila, U., Mahmudatul Imamah, F., \& Sari Dewi, I. (2020). WHY ISLAM IS THE WORLD FASTEST GROWING RELIGIOUS GROUP DESPITE OF TERRORISM ISSUES? AN INITIAL RESEARCH OF TERRORISM ISSUES AND ISLAM AWARENESS. JARES (Journal of Academic Research and Sciences), 5(1), 1-13. https://doi.org/10.35457/jares.v5i1.899
\end{abstract}

(2013) tried to analyse the treath of Islam converts in Europe and suggested that future resarcher should reconsider the concept of a convert stems from a simple but disconcerting observation made during this research since all the European converts to Islam have different motivation range from one to another. While another research said that there is no unanimity regarding its initiating factors, mechanisms or implications or indeed subjects related Islam converts to terrorism issus and in the conversion process there is change of feature definition. In this research noted that religious reorientation in terms of denominational affiliation, practices and/or beliefs is not equivalent to the transformation in the sphere of identity (Harms, 1962). The research by Harms supported by another research show a very range motivation to join Islam. Simonsohn (2017) in his reseach claimed that conversion to Islam afforded various exemptions from the material and social burdens that were required by adherence to a non-Islamic faith and conluded that conversion to Islam was often motivated by material concerns.

In other research showed that some scholars claim to have converted because of personal conviction that there is no god but Allah (Köse, 1996; Suleiman, 2013). Shahid (1999) in his reseach said that people join Islam in their searching for the Truth. While another convert said that Islam atracted by their social culture to helped each other (On Islam, 2014).

Caline Neumueller in her thesis tried to tried to analyse Islam converts in Britain and Germany. She noted that the claim about Islam population by birth rate of muslim family or by migration could easily denied by the fact that two nationwide Islamic organisations, the Zentralrat der Muslime in Deutschland e.V. (Central Council of Muslims in Germany) and the Islamische Gemeinschaft der schiitischen Gemeinden Deutschlands (Islamic Society of Shiite Communities of Germany) have German Muslim converts on their board of directors. She also noted that the initial point for someone to atract to Islam. Some participants' initial interest in Islam included the love of adventure which led them to travel to Muslim majority countries, for others it was a fascination with the Middle East found in literature, film and the media. Others again had a desire for religiosity and spirituality in a secular and materialistic culture, or felt the need for rules in an otherwise chaotic world. Some sought a source of justice in an unjust world, while others cited anti-capitalism, the beauty of the Qur'an, the security of a religious community or the protection against sexism through the hejab as reasons for their conversion. Often there were also personal encounters, whether with a religious scholar or a sheikh, an Islamic preacher, or a Muslim partner, which inspired the individual participant. Some has disappointment in the institution of the Church made several participants leave Christianity, e.g. in Germany the converts not only has religious reasons but also to avoid the obligatory church tax. Thus Neumueller concluded that converted to Islam as a result of being 
JARES, Vol. 5 No. 1 March, 2020; p-ISSN: 2502-826X; e-ISSN: 2503-1163

Copyrights@Balitar Islamic University, Blitar, Indonesia;

https://ejournal.unisbablitar.ac.id/index.php/jares

\begin{abstract}
Citation: Ana Fardila, U., Mahmudatul Imamah, F., \& Sari Dewi, I. (2020). WHY ISLAM IS THE WORLD FASTEST GROWING RELIGIOUS GROUP DESPITE OF TERRORISM ISSUES? AN INITIAL RESEARCH OF TERRORISM ISSUES AND ISLAM AWARENESS. JARES (Journal of Academic Research and Sciences), 5(1), 1-13. https://doi.org/10.35457/jares.v5i1.899
\end{abstract}

attracted to the social lifestyle, fashions, furnishings, architecture, literature and an Islamic way of life, and who viewed Islam as a rational religion (Neumueller, 2012). Awan (2011) also conducted Islam converts in Britain resulted that a Muslim in Britain does not demand recognition by or registration with any legal body or religious institution, in the same way that, for example, conversion to Judaism may. Awan also pointed about the claim Islam population by birth rate and migration by showed that amongst the Muslim population, the following ethnic groups have been denominated as putative converts; Black Caribbean $(4,477)$, White British $(63,042)$, White Irish (890), Mixed White \& Black Caribbean $(1,385)$ giving a total figure of 69,794 . Awan then conluded that the motivation to join Islam more in socio-cultural reason. He claimed there are eleven categories conversion motivation: 1) Conversion as theological or intellectual corroboration, 2) Conversion as lifestyle or perspective reconciliation, 3) Conversion as lifestyle evaluation or reconfiguration, 4) Conversion as political or economic critique or dissent, 5) Conversion as sociocultural critique or dissent, 6) Conversion as religious critique or dissent, 7) Conversion as social matrix reconfiguration, 8) Conversion as relationship consolidation, 9) Conversion as rebellion, 10) Conversion as capitulation, and 11) Conversion as supernatural or mystical concordance (Awan, 2011). Another study by Brice (2010) showed that $96 \%$ converts received help and advice from books, $86 \%$ from moslem friends, $64 \%$ received help from internet, $52 \%$ received help from mosque, $48 \%$ from organization. Those study supported by a study conducted by Alonzo (2014) that concluded the converts believe that they have experienced profound changes due to their external new practices then these conscious choices affect their lifestyle; diet, dress, and prayers making them feel closer to God spiritually.

There is also romance motivation to join Islam proved by several researches. Awang research of Malaysian converts conluded that factors of converting to Islam: guidance from Allah (God), readings, interactions with Malay Muslim community, encouragement from other Muslim families, and marriage (Awang et al, 2015). Also in Malaysia, Chinese Malaysia Conversion reasons mainly two things: intellectual and marriage (Lam, 2004). A study in Indonesia conluded that the motivation to join Islam are: $38.5 \%$ marriage, $34.5 \%$ encouragement from friends, $27 \%$ self awareness (Nikmah, 2013). About marriage motivation to join Islam, Hasin's study showed that Islam converts through marriage has three main reason: respect to parents, to simplify marrital administration, ignorance and or indifferent (Hasin, 2015). Another studies in several countries also showed that many women convert following a romantic relationship with a Muslim, while others convert after learning about the religion from Muslim friends, or actively seek out Muslims in order to learn about Islam in a search for meaning (Roald, 2004, Vroon-Najem, 2014). The latest study 
JARES, Vol. 5 No. 1 March, 2020; p-ISSN: 2502-826X; e-ISSN: 2503-1163

Copyrights@ Balitar Islamic University, Blitar, Indonesia;

https://ejournal.unisbablitar.ac.id/index.php/jares

\begin{abstract}
Citation: Ana Fardila, U., Mahmudatul Imamah, F., \& Sari Dewi, I. (2020). WHY ISLAM IS THE WORLD FASTEST GROWING RELIGIOUS GROUP DESPITE OF TERRORISM ISSUES? AN INITIAL RESEARCH OF TERRORISM ISSUES AND ISLAM AWARENESS. JARES (Journal of Academic Research and Sciences), 5(1), 1-13. https://doi.org/10.35457/jares.v5i1.899
\end{abstract}

also conluded that one of the motivation to join Islam is Marriage (3,3\%). Another reasons are 53\% intellectual, 30\% affectional, 6,7\% mystical, others are experimental, coercive, upward mobility, minister\&married masing-masing 3,3\%. The intellectual reason by read Islamic books, materials, Qur'an and listened to preaching discovered that Islam is reasonable, rational, and logical; the irrational and the hypocritical life of church and some pastors; the ethical, moral, and consistent life of Muslims as stipulated in the Quran. The affectional reason are: Marriage especially among women, Caring attitude of Muslims, Muslims' benevolence via scholarship, gift, and healing (Priest, 2018).

From those studies showed that the motivation to join Islam mostly by the intellectual reason. It could be because the most converts are youth or at least below senior (20-49 years old) (International Centre for Muslim and non-Muslim Understanding, 2015). This result supported by another study showed that converts (over 60\%) fall within the 23-45 age group, with a significant proportion (over 25\%) in the 17-22 age group (Kose 1996: 47; Berrington 1993). Youth has many access to information by many media platforms especially internet. They able to know information about some issues correlated to Islam exposed by media in news and movies that motivate them to investigate more about Islam.

\title{
DISCUSSION
}

Media through news and movies tend show a negative point of view about Islam but world's muslim population getting larger in the latest decades. One of TV show in BBC documentary entitled My Son the Jihadi (October, 2015) and My Brother the Islamist, aired on BBC Three in April 2011, both portraited a very negative, biased and stereotypical representations of modern-day White British converts to Islam. In the show they told a story about a minority of converts who then join to radical Muslim groups and become extremists. News article and news TV program in regular basis also show and or pointed a view of terrorism attack that has been done by muslim converts who then involve in extrimist group (Alyedreessy, 2016).

Despite stereotype and prejudice of correlated with extrimisms, radicalisms and terrorism attacks, caused a curiosity about what is motivation behind Islam converts and what initiated them at the first place. In europe some report said that this continent has the fastest muslim grows in the world, some observers show a worry about cultural change, some worry about potential of converts turn into radical, some worry about a minority group will become a super minority group in the society (Brice, 2010; Moosavi, 2012), and even some worry about the change about politic, economy 
JARES, Vol. 5 No. 1 March, 2020; p-ISSN: 2502-826X; e-ISSN: 2503-1163

Copyrights@Balitar Islamic University, Blitar, Indonesia;

https://ejournal.unisbablitar.ac.id/index.php/jares

\begin{abstract}
Citation: Ana Fardila, U., Mahmudatul Imamah, F., \& Sari Dewi, I. (2020). WHY ISLAM IS THE WORLD FASTEST GROWING RELIGIOUS GROUP DESPITE OF TERRORISM ISSUES? AN INITIAL RESEARCH OF TERRORISM ISSUES AND ISLAM AWARENESS. JARES (Journal of Academic Research and Sciences), 5(1), 1-13. https://doi.org/10.35457/jares.v5i1.899
\end{abstract}

and law.

In Brice study (2010) resulted that from total number of converts has been estimated at 100,000 , with as many as 5,000 conversions per year and mostly for marriage reason. Brice also showed that his study againts popular belief of a fear that society will not accept Islam converts. It has been show that converts' friends and family become more positive to Islam over time (Brice, 2010). Since the contradictionary between the stereotype and muslims population around the world, many academic interest about Islam and awareness about Islam grow fast. Some of the researcher focused on giving more comprehend translation and interpretation about Islam books and other literatures since before it said to be unjustified.

The conversion of spiritual it self is 'the search for significance in ways related to the sacred'. These two quotes are based on the search of 'The Divine' or 'God', and are usually applied to the active seeker. The search may start from an emotional crisis, such as a death in the family, or from an intellectual quest driven by curiosity and determination to 'seek the truth', 'know The Creator' or seek the 'purpose of life and human existence'. Individuals who find answers in religion and via a connection to God through prayers are more likely to achieve peace of mind, a goal to work towards, and a different perspective of the world and life, which contributes to the regeneration of the spiritual self and reformation of morals, character and identity (Pargament, 1997). Max Heinrich claimed there are 4 spiritual conversion definition based on the field study: 1) for scientist spiritual conversion is the guidance of God, 2. For sosiologyst spiritual conversion is caused by social influence (personal relationship, propaganda, habitaul, missionary, and group influence), 3. For educator spiritual conversion happen in education institution formal or non-formal, 4. Psychologyst define spiritual conversion as the psychological factors encourage conversion (Puspito, 1984: 189). Donald Taylor (1999) explains his theory about conversion in three parts: 'inward', 'outward', and 'awkward' conversion. 'Inward' conversion implies the notion of moving away from an inferior to a superior tradition, based on both the convert's perspective and those in the receiving tradition. 'Outward' conversion focuses on the perspective of a group that an individual or 'apostate' leaves behind and does not acknowledge the individual's change as being conversion. 'Awkward' conversion explains conversion through marriage. These definitions of spiritual conversion already explain that conversion has a long process and this process might be different for each person. This rich diversity is often ignored or neglected, which Poole (2002: 187) argues is largely a consequence of inaccurate or deliberately skewed media coverage, as if the press has only one idea about Islam.

A study found that when someone interested about Islam, they will found that Islam teachings need to applied into their daily lives thus somehow influenced their identity developments, 
JARES, Vol. 5 No. 1 March, 2020; p-ISSN: 2502-826X; e-ISSN: 2503-1163

Copyrights@Balitar Islamic University, Blitar, Indonesia;

https://ejournal.unisbablitar.ac.id/index.php/jares

\begin{abstract}
Citation: Ana Fardila, U., Mahmudatul Imamah, F., \& Sari Dewi, I. (2020). WHY ISLAM IS THE WORLD FASTEST GROWING RELIGIOUS GROUP DESPITE OF TERRORISM ISSUES? AN INITIAL RESEARCH OF TERRORISM ISSUES AND ISLAM AWARENESS. JARES (Journal of Academic Research and Sciences), 5(1), 1-13. https://doi.org/10.35457/jares.v5i1.899
\end{abstract}

experiences, and hardships in the society. The converts mostly first learn about Islam by reading the biography of Prophet Muhammad before learn about Quran and other literature since they need to know person related the religion. In the process of investigating Islam and apply to be a lifestyle someone could feel isolated for especially the converts with unsupported family and friends but many of participants showed the opposite (Alyedreessy, 2016). More study showed Islam atracted people from its affection cultural. It is not all wrong when some observers claimed that some muslim converts are from minority group. Islam provided these converts with a way of unifying their preexisting egalitarian views with their predisposition (because of their religious backgrounds) to "spiritual" experiences. In the process to recognize Islam, new comers also think that Islam able to reconcile questions about the relationship of religion with logic, provide an alternative to the apparent contradictions in their former religion, or, alternatively, appear as congruent with the aspects of their former religion that they liked. Individuals are attracted to this religion despite conversion to it having a perceived decline in social status (Zebiri, in Bowen, 2009).

There is a fidgetness of muslim converts from Jews or Christian community since their conversion would be called as apostate therefore these converts would find social difficulty because they have to back to their home in the community (Simonsohn, 2013). One reason probably encourage someone to join Islam is that joining Islam has nothing administration to proceed thus make a new comer more comfortable and can follow the process of their faith journey to join Islam completely. Another reason is that the availability of direction resources from kin relationship, in addition to the existing constant contact with the Muslim community, aided the converts' ritual and lifestyle experimentation without the need to seek guidance from religious missionaries (Kumpoh, 2011).

These stages emphasise the complex set of factors that can affect the individual's decisionmaking process, such as marriage, commitment, or the need for spiritual security and social belonging. The conversion process: 1). Cultural, social, personal and religious context of the affected person; 2). A crisis as a trigger for change; 3). The search for fulfilment and their motives; 4). Meeting with advocates of the new religion/ religious community; 5). Interaction and emergence of obligations; 6). The rhetoric and acquisition of new roles by the converts; and 7). Ties and obligations (acceptance by the convert as well as the effects and consequences associated with the conversion (Rambo, 1993). Norman Skonovd (1981) focused on the 'motifs' that seemed to characterise conversions rather than the conversion process itself. These six motifs are: 1) intellectual conversion; 2) mystical conversion; 3) experimental conversion; 4) affectional conversion; 5) revivalist conversion (crowd conformity); and 6) coercive conversion (by external 
JARES, Vol. 5 No. 1 March, 2020; p-ISSN: 2502-826X; e-ISSN: 2503-1163

Copyrights@Balitar Islamic University, Blitar, Indonesia;

https://ejournal.unisbablitar.ac.id/index.php/jares

\begin{abstract}
Citation: Ana Fardila, U., Mahmudatul Imamah, F., \& Sari Dewi, I. (2020). WHY ISLAM IS THE WORLD FASTEST GROWING RELIGIOUS GROUP DESPITE OF TERRORISM ISSUES? AN INITIAL RESEARCH OF TERRORISM ISSUES AND ISLAM AWARENESS. JARES (Journal of Academic Research and Sciences), 5(1), 1-13. https://doi.org/10.35457/jares.v5i1.899
\end{abstract}

pressure to convert).

It seems like the majority of the researchers in the field of conversion to Islam acknowledge the growth in conversion following September 11 and that the major reason behind it lies in increased media exposure. Once again the power of media has been demonstrated, and shown that even negative connotations can bring the same level of attention like the positive one (Sturm, 2017). Zebiri (2014) sees a higher rate of conversion which followed September 11 as "that these events give rise to a curiosity resulting in higher sales of books on Islam and more enquiries at mosques and Islamic organizations." There are only about a total estimated 100,000 militant extremist Muslims in the world. That is less than $0.01 \%$ of the global Muslim population of 1.7 billion people (P. Bergen and Schneider, 2014). Media coverages about Islam gain the number of people's curiosity. Almost in every news and film about radical, media will expose Islam thus people feel the urgency to learn about Islam. A study by Kearns et al (2017) reported that although the fact that the most terror attacks in the Western world (Europe, USA) are committed by non-Muslims, yet terrorist attacks by Muslims receive 449\% more media coverage than other attacks from 2011-2015. After 9/11 many Americans investigate Islam then convert to Islam. Schreffler said that media feed people much about Islam as terrorist then they started to investigate to Islam and probably found the pure of real Islam and decided to converts. ( in an interview with author September 25, 2010 reported by Esseissah, 2011).

The attacks gave many literatures about Islam, in every media platform, journals, articles tried to prove the threat of Islam radical's group and, the opposite, tried to explain the pure teaching about Islam then prove that this religion has nothing to do with the attacks. Gallups polls reported that majority of U.S. Muslims (78\%) stated that it is never morally justifiable to target and kill civilians; meanwhile, only $38 \%$ of Protestants, $39 \%$ of Catholics, $43 \%$ of Jews, $33 \%$ of Mormons, and $56 \%$ of people with no religion/atheists/agnostics stated that it is never morally justifiable to target and kill civilians (in Friedersdorf, 2011). Another study tried to analyse the bomber in many attacks and found that most of the converts that then joined in radical's groups have a problematic background, have little knowledge of Islam and appear to be easily influenced. (Schuurman et al, 2016).

Olaimy in We Forum wrote some interested fact about the bomber in some well known attacks. Belgacem was the gun attacker in Orly airport, the police report said that he had long criminal history includes drug dealing, armed robbery, theft and receipt of stolen goods (postmortem toxicology tests revealed the presence of alcohol, cannabis and cocaine in his blood). Salman Ramadan Abedi, the Manchester Arena suicide bomber, was a regular party-goer who drank vodka and smoked marijuana, according to reports from his friends. Mohamed Lahouaiej-Bouhlel 
JARES, Vol. 5 No. 1 March, 2020; p-ISSN: 2502-826X; e-ISSN: 2503-1163

Copyrights@ Balitar Islamic University, Blitar, Indonesia;

https://ejournal.unisbablitar.ac.id/index.php/jares

\begin{abstract}
Citation: Ana Fardila, U., Mahmudatul Imamah, F., \& Sari Dewi, I. (2020). WHY ISLAM IS THE WORLD FASTEST GROWING RELIGIOUS GROUP DESPITE OF TERRORISM ISSUES? AN INITIAL RESEARCH OF TERRORISM ISSUES AND ISLAM AWARENESS. JARES (Journal of Academic Research and Sciences), 5(1), 1-13. https://doi.org/10.35457/jares.v5i1.899
\end{abstract}

who drove a truck through a Bastille Day parade in Nice and killed 86 people for his answered to ISIS called was far from being a devoted, practising Muslim, because in his daily life he ate pork and had a penchant for alcohol, drugs and promiscuous sex, with both men and women. Al Olaimy claimed that the attacks had no longer religion reason but more social, economic or political measures. Therefore in the further study he suggests that the researcher shouls has focus on social and emotional reasons for extremist behaviour, a human-centred approach to be able to understand the radical behaviour (Al Olaimy, 2017).

\title{
CONCLUSION
}

There's possibility that terrorism, extrimism and radical of Islam exposed by media through news and movies initiated someone to investigate about Islam and somehow decided to learn about Islam. But this could not be conluded absolutely as the only reason to join islam since the motivation of joining a religion could not be one reason and there tend to be long process for someone to be a completely convert. This research need to supported by further research both in quantitative and qualitative research to complete the analyse of terrorism, extrimism and radical of Islam news and movies and world's Islam population.

\section{REFFERENCES}

[1] Al Olaimy, Leena. (2017, July 27). Terrorists Don't Kill for Their Religion. It's Something Else Entirely. World Economic Forum. Retrived from https://www.weforum.org/

[2] Alonzo, Amalia. (2014). Latinas Converting to Islam in New York: Habitus' Influence in Modern Identity Formation. CUNY Academic Works. Retrieved from https://academicworks.cuny.edu/gc_etds/161.

[3] Alyedreessy, Mona. (2016). British Muslim Converts: An Investigation of Conversion and DeConversion Processes to and from Islam (Doctoral dissertation). Kingston University, London, England.

[4] Awan, Akil N. (2011). Conversion to Islam in Contemporary Britain: Motivations,processes and Consequences (Doctoral Dissertation). University of London, UK.

[5] Awang, Azarudin, Khadijah Mohd Khambali, Hambali. (2015). A Study on Factors that Encourages Chinese Muslim Community within Dialogue of Life. Journal of Basic and Applied Scientific Research. 5:1. Pp 45-53.

[6] Bartoszewicz, Monika Gabriela. (2013). Controversies of Conversions: The Potential Terrorist Threat of European Converts to Islam (Thesis). Retrieved from http://researchrepository.st-andrews.ac.uk/.

[7] Bawer, Bruce. (2006). While Europe Slept: How Radical Islam Is Destroying the West from Within. Doubleday, New York.

[8] Becker, Carl H. (1924-1932). Islamstudien, 2 vols. Leipzig.

[9] Bowen, Patrick D. (2009). Conversion to Islam in the United States: A Case Study in Denver, Colorado. Intermountain West Journal of Religious Studies. 1:1, pp. 41-64. 
JARES, Vol. 5 No. 1 March, 2020; p-ISSN: 2502-826X; e-ISSN: 2503-1163

Copyrights@ Balitar Islamic University, Blitar, Indonesia;

https://ejournal.unisbablitar.ac.id/index.php/jares

Citation: Ana Fardila, U., Mahmudatul Imamah, F., \& Sari Dewi, I. (2020). WHY ISLAM IS THE WORLD FASTEST GROWING RELIGIOUS GROUP DESPITE OF TERRORISM ISSUES? AN

INITIAL RESEARCH OF TERRORISM ISSUES AND ISLAM AWARENESS. JARES (Journal of Academic Research and Sciences), 5(1), 1-13. https://doi.org/10.35457/jares.v5i1.899

[10] Brice M.A.K. (2010). A minority Within a Minority: A Report on Converts to Islam in the United Kingdom. Faith Matters Report.

[11] Brice, M. A. Kevin. (2010). A Minority Within A Minority: A Report On Converts To Islam in The United Kingdom. Faitth Matters. UK.

[12] Bulliet, Richard W. (1979). Conversion to Islam in the Medieval Period: An Essay in Quantitative History. Cambridge, MA.

[13] Caldwell, Christopher. (2009). Reflections on the Revolution in Europe: Immigration, Islam, and the West. Doubleday, New York.

[14] Congressional Research Service. (2011, September 7). Muslims in Europe: Promoting Integration and Countering Extremism. Retrieved from http://www.crs.gov.

[15] Danios. (2011, August 7). Surveys Show Muslims in Every Country Less Likely to Justify Killing Civillians than Americans and Israelis. Loonwatch. Retrieved from http://www.loonwatch.com/2011/08/surveys-show-muslims-in-every-country-less-likelyto-justify-killing-civilians-than-americans-and-israelis/.

[16] Eaton, Richard M. (1996). The Rise of Islam and the Bengal Frontier 1204 - 1760, 1st Edition. University of California Press, USA.

[17] Esseissah, Khaled. (2011). The Increasing Conversion to Islam Since 9/11: A Study of White American Muslim Converts in Northwest Ohio (Thesis). Bowling Green State University, USA.

[18] Friedersdorf, Conor. (2011, August 3). A Fascinating Look at the Political Views of Muslim Americans. The Atlantic. Retrieved from https://www.theatlantic.com/politics/archive/2011/08/a-fascinating-look-at-the-politicalviews-of-muslim-americans/242975/

[19] Geaves, R. (2010). Islam in Victorian Britain: The Life and Times of Abdullah Quilliam. Leicester: Kube Publishing.

[20] Hanggoro, Marcheilla Ariesta Putri. (2016, February 2). 5 Negara ini umat Islamnya bertambah paling cepat sedunia. Merdeka Com. Retreived from https://www.merdeka.com/.

[21] Harms, E. (1962). Ethical and Psychological Implications of Religious Conversion. Review of Religious Research. 3:3, pp. 122-131.

[22] Hasin, Atabik. (2015). Masuk Islam karena Alasan Perkawinan: Studi Kasus Perkawinan Pasangan yang Semula Beda Agama di Desa Borangan Kecamatan Manisrenggo Kabupaten Klaten (Undergraduate Thesis). Universitas Islam Negeri Walisongo Semarang, Indonesia.

[23] Holland, Joshua. (2015, December 2). Here's What a Man Who Studied Every Suicide Attack in the World Says About ISIS's Motives. The Nation. https://www.thenation.com/article/heres-what-a-man-who-studied-every-suicide-attackin-the-world-says-about-isiss-motives/

[24] International Centre for Muslim and non-Muslim Understanding. (2015, 1 June). Australian Muslims: A Demographic, Social and Economic Profile of Muslims in Australia 2015. University of South Australia, Australia.

[25] Kearns, Erin M. and Betus, Allison and Lemieux, Anthony. (2017). Why Do Some Terrorist Attacks Receive More Media Attention Than Others? Retrieved from https://papers.ssrn.com/sol3/papers.cfm?abstract_id=2928138.

[26] Köse A. (1996). Conversion to Islam: A Study of Native British Converts. London: Kegan Paul International.

[27] Kumpoh, Asiyah az-Zahra Ahmad. (2011). Conversion to Islam: The case of the Dusun ethnic group in Brunei Darussalam (Doctoral dissertation). University of Leicester, UK. 
JARES, Vol. 5 No. 1 March, 2020; p-ISSN: 2502-826X; e-ISSN: 2503-1163

Copyrights@ Balitar Islamic University, Blitar, Indonesia;

https://ejournal.unisbablitar.ac.id/index.php/jares

Citation: Ana Fardila, U., Mahmudatul Imamah, F., \& Sari Dewi, I. (2020). WHY ISLAM IS THE WORLD FASTEST GROWING RELIGIOUS GROUP DESPITE OF TERRORISM ISSUES? AN

INITIAL RESEARCH OF TERRORISM ISSUES AND ISLAM AWARENESS. JARES (Journal of Academic Research and Sciences), 5(1), 1-13. https://doi.org/10.35457/jares.v5i1.899

[28] Lam, Joy Y. (2004, November). Religious Conversion and Reconstruction of Identities: The Case of Chinese Muslim Converts in Malaysia. Southeast Asia Research Center Working Paper Series. No 74. Retrieved from http://www.cityu.edu.hk/searc.

[29] Lofland, J. and Skonovd, N. (1981). Conversion Motifs. Journal for the Scientific Study of Religion. 20, pp. 373-385.

[30] Long T. E. \& Hadden, J. K. (1983). Religious Conversion and the Concept of Socialization: Integrating the Brainwashing and Drift Models. Journal for the Scientific Study of Religion. 22:1, pp. 1-14.

[31] Mistiaen V. (2013, October 11). Converting to Islam: British Women on Prayer, Peace and Prejudice. The Guardian. http://www.theguardian.com/world/2013/oct/11/islam--converts---british---women---prejudice.

[32] Moosavi L. (2013, May 24). Are Converts More Likely to be Extremists than Other Muslims? The Guardian. http://www.theguardian.com/commentisfree/belief/2013/may/24/islamconverts-woolwich-attackers-extremists.

[33] Neumueller, Caroline. (2012). The 21st Century New Muslim Generation Converts in Britain and Germany (Doctoral dissertation). University of Exeter, UK.

[34] Nikmah, Laili Ilmi. (2013). Peran Majelis Muhtadin Al-Falah dalam Membimbing Muallaf di Masjid Al-Falah Surabaya Tahun 2009 (Undergraduate Thesis). UIN Sunan Ampel Surabaya, Indonesia.

[35] On Islam. (2014). Why I Chose Islam?: Stories About New Muslims' Journeys to Islam. Retrieved from http://www. OnIslam.net. pp 9-12.

[36] Özyürek, Esra. (2015). Being German, Becoming Muslim: Race, Religion and Conversion in the New Europe. Princeton University Press, Princeton and Oxford.

[37] P. Bergen and E. Schneider. (2014, September 26). Bergen Schneider: How Many Jihadits. CNN. http://us.cnn.com/2014/09/26/opinion/bergen-schneider-how-manyjihadists/index.html

[38] Pargament, K. I. (1997). The Psychology of Religious Coping: Theory, Research, Practice. New York: Guilford Press. P 32.

[39] Pew Research Center. (2015, April 2). The Future of World Religions: Population Growth Projections, 2010-2050. Retrieved from www.pewresearch.org.

[40] Poole, E. (2002). Reporting Islam: Media Representations of British Muslims. London: I B Taurus.

[41] Priest, Chinyere.F. (2018). Conversion to Islam: A Study of Igbo Christians to Islam [Presentation Slides from 8th Lausanne International Researchers' Conference, APRIL 30 TH - MAY 5]. Retrieved from http://www.globalcmiw.org.

[42] Puspito, Hendro. (1984). Sosiologi Agama, Cet. Ke-2.. Yogyakarta: Kanisius.

[43] Rambo, L. (1993). Understanding Religious Conversion. New Haven, CT: Yale University Press.

[44] Rieff, David. (2010, January/February). Fermez la Porte: The Oversimplification of Europe. World Affairs. Retrieved from http://www.worldaffairsjournal.org/article/fermez-la-porteoversimplification-europe.

[45] Roald, Anne Sofie. (2004). New Muslims in the European Context: The Experience of Scandinavian Converts. Brill, Leiden.

[46] Rogozen-Soltar, Mikaela. (2012). Managing Muslim Visibility: Conversion, Immigration, and Spanish Imaginaries of Islam. American Anthropologist. 114:4. pp 611-623.

[47] Salaymeh, Lena. (2016). Taxing Citizens: Socio-legal Constructions of Late Antique Muslim Identity. Islamic Law and Society. 23:4, pp. 333-367. 
JARES, Vol. 5 No. 1 March, 2020; p-ISSN: 2502-826X; e-ISSN: 2503-1163

Copyrights@ Balitar Islamic University, Blitar, Indonesia;

https://ejournal.unisbablitar.ac.id/index.php/jares

\section{Citation: Ana Fardila, U., Mahmudatul Imamah, F., \& Sari Dewi, I. (2020). WHY ISLAM IS THE WORLD FASTEST GROWING RELIGIOUS GROUP DESPITE OF TERRORISM ISSUES? AN \\ INITIAL RESEARCH OF TERRORISM ISSUES AND ISLAM AWARENESS. JARES (Journal of Academic Research and Sciences), 5(1), 1-13. https://doi.org/10.35457/jares.v5i1.899}

[48] Schuurman, B., P. Grol and S. Flower. (2016). Converts and Islamist Terrorism: An Introduction. The International Centre for Counter-Terrorism - The Hague. 7:3.

[49] Shahid, Muhammad Haneef. (1999). Yes! I Converted to Islam and here is Why?. Darussalam. New York, USA. pp 11-12.

[50] Simonsohn, Uriel. (2013). Conversion to Islam: A Case Study for the Use of Legal Sources. History Compass. 11: 8, pp. 647-662.

[51] Simonsohn, Uriel. (2017). Conversion, Exemption, and Manipulation: Social Benefits and Conversion to Islam in Late Antiquity and the Middle Ages. Medieval Worlds. No. 6, pp. 196-216. DOI 10.1553/medievalworlds_no6_2017s196.

[52] Straus, R. A. (1979). Religious Conversion as a Personal and Collective Accomplishment. Sociological Analysis. 40:2, pp. 158-165.

[53] Sturm, Nika. (2017). Northwest European Female Conversion to Islam and Conceptualization of Prejudices, Discrimination and "Otherness". Uppsala University, Sweden.

[54] Suleiman Y. (2013). Narratives of Conversion to Islam in Britain: Female Perspectives. Cambridge: Cambridge University.

[55] Tausch, Arno. (2017, September 25). How Many Muslims Still Support Terrorism?. Telospress. Retrieved from http://www.telospress.com/.

[56] Taylor J. And Morrison S. (2011, January 4). The Islamification of Britain: Record Number Embrace Muslim Faith. The Independent Tuesday. http://www.independent.co.uk/news/uk/home---news/the---islamification---of---britain--record---numbers---embrace---muslim---faith---2175178.html.

[57] Taylor, D. (1999). Converting: Inward, Outward and Awkward. In: C. Lamb and D. Bryant, eds, Religious Conversion: Contemporary Practices and Controversies. London and New York: Cassell, pp. 35-45.

[58] Vaisse, Justin. (2010, January 4). Eurabian Follies. Foreign Policy. Retrieved from https://foreignpolicy-com/2010/01/04/eurabian-follies/

[59] Vroon-Najem, Vanessa. (2014). Sisters in Islam: Women's Conversion and the Politics of Belonging: A Dutch Case Study (Doctoral dissertation). Amsterdam Institute for Social Science Research, Netherlands.

[60] Why are So Many Westerners Converting to Islam?. (2015, July 14). CBN. Retrieved from http://www1.cbn.com/spirituallife/why-are-so-many-westermers-converting-to-Islam.

[61] Zebiri, Kate. (2014). British Muslim Converts: Choosing Alternative Lives. New York: Oneworld Publications.

[62] Zygmunt, J. F. (1972). When Prophecies Fail. American Behavioral Scientist. 16:2, pp. 245268. 